divide is unfamiliar, the Japanese work on monkeys is not ordinarily known, Wallace's line is hotly disputed, the turret-rocks of Formosa are baffling, and where can one learn more about the stupendous scenes of the Himalayas? Such a fine book, produced with such experience and craftmanship, ought to last; it would if it led on.

E. J. H. CORNER

\title{
Where the Sea Breaks its Back by Corey Ford. Gollancz, 30s.
}

This is two tales in one: the story of Vitus Bering's voyage of discovery from Kamchatka to Alaska in 1741 and nightmare journey back, and of the remarkable wildlife discoveries of that brilliant, bitter, arrogant, tactless, irascible German naturalist and scientist, the ship's mineralogist, Georg Wilhelm Steller, whose name as a result of this yoyage is commemorated in four birds, one fish, three geographical features and the giant northern manatee, the now extinct Steller's sea cow. When they did discover Alaska Steller, to his fury and despair, was allowed only ten hours ashore - 'ten years the preparation, ten hours to do the work itself', as he bitterly recorded in his diary - and even that was only achieved after a blistering attack on Bering to his face for which 'any other member of the crew would have been clapped in irons'. The wreck of the ship on Bering Island after a return voyage of storm and disaster along the Aleutian chain - 45 of the crew of 77 died, including the captain, mostly of scurvy, which Steller could have prevented if they had heeded him - at least gave Steller eight months in which to study the flora and fauna. Sea otters, blue foxes - which sniffed at the dying, ate the dead and dug up the buried corpses - fur seals, sea lions, all were studied and meticulously described, and above all the huge sea cows, never seen before or since by any scientist.

A new boat, built out of the wreck on Bering Island, brought the survivors back to Kamchatka, and with them the news of the fur seals and sea otters. Next spring the massacre began.

This well told, dramatic and tragic story is based on Steller's own journal. In a final chapter the author tells briefly what has happened to the sea otters of Alaska since Steller's day - a story of slaughter and cruelty, but with a happier outcome today than could have seemed possible fifty years ago.

M. S. FITTER

\section{Conservation and Caribbean Regional Progress by Carl A. Carlozzi} and Alice A. Carlozzi. Antioch Press, Yellow Springs, Ohio, $\$ 4.00$. This little 160-page book deals with the Lesser Antilles, 22 intriguing islands aggregating less than 5000 square miles. Without pretension as to scientific thoroughness, it discusses, among other natural and historic features, the vertebrate fauna and its current plight.

Because of the geological youth of the islands, vertebrates were never abundant. Birds and reptiles predominate. Mammals are rare. Except on Trinidad the birds are mostly inconspicuous. Parrots are found on Dominica, St Lucia, St Vincent, and Bonaire. Introduced birds of paradise persist on Little Tobago. The scarlet ibis and oil birds of Trinidad are mentioned, as are the flamingos of Bonaire. Howler monkeys are found on Trinidad, and smaller species are feral on St Kitts, Nevis, and Grenada. Green turtles are listed for Barbuda and Bonaire.

The fauna of these islands is disappearing. As a result of destruction of most of the original plant communities for agriculture in the seventeenth and eighteenth centuries, introduced predators such as the mongoose and the monkeys, and excessive hunting, some 21 vertebrate species or subspecies endemic to these islands have already disappeared. Included are ten birds. Thirty-six more vertebrates, including 16 birds (all the parrots) are threatened. 
Efforts to protect the fauna, although increasing, are still inadequate. Protective legislation is widespread but not well enforced. The ten private or quasi-public conservation organisations, with impressive exceptions such as the Friends of English Harbor and the Barbados Natural Trust, are mostly only beginning to become influential.

The Carlozzis show that conservation of natural and historic features underlies the chief hope for economic survivial of these islands - tourism. The needs they foresee include research, educational guidance, strong conservationoriented institutions, physical planners, land acquisition, and expertise in site development. To pool efforts and to encourage both local and necessary outside support, they propose a Caribbean International Park System. If the mutual benefits can sufficiently attract these individualistic islands to such a scheme, other advantages are obvious.

F. H, WADSWORTH

\section{Man and the California Condor by Ian McMillan. Dutton, New York,} $\$ 5.95$.

The author is a rancher whose home is within the mountainous horseshoe of country which dips to within 20 or $\mathbf{3 0}$ miles of Los Angeles at the southern end and stretches two arms northward for 150 miles along either side of the San Joaquin Valley. This also is 'condor' country, and in 1963 he and two others were commissioned by the Audubon Society to report on the status of this immense vulture. The California condor Gymnogyps californianus had last been censused in the 1940's by Carl Koford who put the total stock at 60 ; McMillan estimated that it had dropped to 46 . He discusses the causes of this sharp decline in 20 years. First, in historical sequence, it was shot; then its eggs were collected. As these activities declined it began to suffer disturbance in its remote breeding places by the opening up of wilderness areas to tourism, or by burning off scrub to increase forage; after that poisons and finally pesticides. One does not gather that during the last 50 years it has been subject to exceptional pressures but its slow rate of reproduction due to the bird not breeding until about its sixth year and the laying of a single egg every other year makes it extremely sensitive to loss. The author comments on the rather dim attitude of the forest authorities, who are officially charged with the conservation of the condor, to their responsibilities, and ponders on the final irony of trapping condors for captive breeding in zoos.

The California condor can be saved in the wilderness: 'If man chooses to do so, and with no more than a token sacrifice, he can live with the condor.' The book is well illustrated with good photographs of condors and the country they live in.

G. DES FORGES

\section{Journey to Red Birds by Jan Lindblad. Collins, $36 s$.}

This is a pleasant, informal account of how the author visited Trinidad and Tobago, with side excursions to Bonaire and Brazil, and successfully filmed some of those islands' most remarkable and beautiful birds, especially the scarlet ibis and oilbirds of Trinidad. A good deal of varied natural history is mixed with the narrative, and there is an accompaniment of 24 excellent colour photographs and 26 black-and-white. But perhaps the most valuable point that the author makes is the urgent need for far more effective conservation of these and other striking, and in some cases unique, animals in a part of the world that is rapidly becoming over-congested, developed, and tourist-ridden. The scarlet ibis, Trinidad's national bird, has a breeding colony within sight of Port-ofSpain, and no other regular breeding colonies of this dazzling bird appear to be 